\title{
PENGGUNAAN MODEL REGRESI LINIER BERGANDA UNTUK MENGETAHUI PENGARUH PEMBANGUNAN LIPPO PLAZA TERHADAP NILAI TANAH (STUDI KASUS : LIPPO PLAZA, KEC. KALIWATES, KAB. JEMBER)
}

\author{
Udiana Wahyu Deviantari ${ }^{* 1}$, Dwi Noviyanti ${ }^{1}$, Andy Dediyono ${ }^{2}$ \\ ${ }^{1}$ Departemen Teknik Geomatika, FTSLK-ITS, Kampus ITS Sukolilo, Surabaya, 60111, Indonesia \\ ${ }^{2}$ Masyarakat Profesi Penilai Indonesia \\ e-mail: ${ }^{* 1}$ dianada87@gmail.com
}

\begin{abstract}
Abstrak
Salah satu kecamatan dengan jumlah penduduk dan kepadatan tertinggi adalah Kecamatan Kaliwates yang memiliki luas wilayah $24.94 \mathrm{~km}^{2}$. Kecamatan Kaliwates merupakan pusat perekonomian di Kabupaten Jember. Keberadaan Lippo Plaza di Kecamatan Kaliwates Jember diharapkan dapat memberikan kontribusi baik bagi pemerintah melalui penciptaan lapangan pekerjaan, pergerakan roda perekonomian daerah, kontribusi pajak, dan melalui sosial kemasyarakatan. Dampak dari pembangunan Lippo Plaza sebagai fasilitas pusat perbelanjaan di Kecamatan Kaliwates ini akan berpengaruh terhadap meningkatnya nilai tanah disekitar wilayah tersebut.

Dalam memprakirakan nilai tanah digunakan suatu pemodelan matematis. Metode yang digunakan adalah metode regresi linier berganda. Metode Regresi Linier berganda dipilih karena dapat digunakan untuk menentukan model matematika, sehingga dapat digunakan untuk menyelidiki atau menganalisis hubungan antara nilai tanah dengan variabel penentunya.

Pada penelitian ini diperoleh model regresi linier dengan persamaan $Y=26,187+38,921$ komersil $+0,049 \times 2$ - 7,022 X1. Variabel Komersil, Jarak ke Pusat Kota (X2), Jarak ke Lippo (X1) mempengaruhi nilai tanah secara signifikan terhadap nilai tanah. Peta Zona Nilai Tanah yang dihasilkan dari NIR model dengan wilayah yang memiliki nilai tanah paling tinggi berada di wilayah komersil dan berada di radius $1 \mathrm{~km}$ dari Lippo Plaza. Untuk wilayah yang memiliki nilai tanah paling rendah berada di lahan pertanian, perumahan, dan permukiman serta berada di radius $3 \mathrm{~km}$ dari Lippo Plaza.
\end{abstract}

Kata kunci-NJOP, Regresi Linier Berganda, Zona Nilai Tanah

\section{PENDAHULUAN}

Kecamatan Kaliwates merupakan salah satu Kecamatan yang ada di Kabupaten Jember. Kecamatan Kaliwates memiliki jumlah penduduk dan kepadatan tertinggi. Menurut data yang telah dihimpun kepadatan penduduk di Kecamatan ini mencapai 4.136 jiwa per $\mathrm{km} 2$ serta jumlah penduduk yang mencapai 111.861 jiwa (Purwaningsih, 2016).

Letak Kecamatan Kaliwates yang strategis karena dilewati oleh jalur utama antar kota membuat daerah ini semakin diperhitungkan oleh investor untuk mengembangkan usahanya. Salah satu dari perkembangan di kecamatan ini adalah pembangunan pusat perbelanjaan Lippo Plaza yang sudah mulai beroperasi pada tahun 2017 (Setia, 2017).

Menurut penelitian yang telah dilakukan oleh Kurniati diketahui bahwa dampak dari pembangunan Lippo Plaza sebagai fasilitas pusat perbelanjaan di Kecamatan Kaliwates ini akan berpengaruh terhadap meningkatnya nilai tanah disekitar wilayah tersebut (Kurniati, 2017).

Nilai tanah merupakan perwujudan dari kemampuan tanah memproduksi sesuatu sehingga dapat memberikan keuntungan ekonomi. Nilai tanah akan mencapai nilai tertinggi jika mempunyai semua faktor-faktor penentu nilai tanah, atau jika salah satu faktor penentu nilai tanah sangat kuat pengaruhnya terhadap kawasan sekitarnya (Yullyan, 2016). Nilai tanah memiliki hubungan fungsional terhadap harga tanah. Jika nilai tanah tinggi maka dipastikan harga tanah juga akan tinggi. Harga tanah merupakan proyeksi dari tinggi rendahnya nilai tanah (Safitri, 2016).

Pada penelitian ini, dilakukan kajian tentang pengaruh nilai tanah terhadap pembangunan Lippo Plaza. Metode yang digunakan dalam penelitian ini menggunakan metode regresi linier berganda. Metode ini digunakan untuk menentukan model matematis yang paling sesuai untuk pasangan data serta menganalisis hubungan antar variabel yang 
telah ditentukan.

\section{METODE}

Lokasi Penelitian

Lokasi penelitian terletak di Kecamatan Kaliwates dengan koordinat $8^{\circ} 09^{\prime} 54,6^{\prime \prime}$ LS $113^{\circ} 38^{\prime} 21,9^{\prime \prime}$ BT sampai dengan $8^{\circ} 12^{\prime} 53,1^{\prime \prime}$ LS $113^{\circ} 42^{\prime} 50,0^{\prime \prime}$ LS sampai dengan luas wilayah $24,94 \mathrm{Km}^{2}$

Batas - batas wilayah meliputi:

Utara : Kelurahan Kapor

Barat : Kelurahan Kraton

Selatan : Desa Langkap

Timur : Kelurahan Benangkah

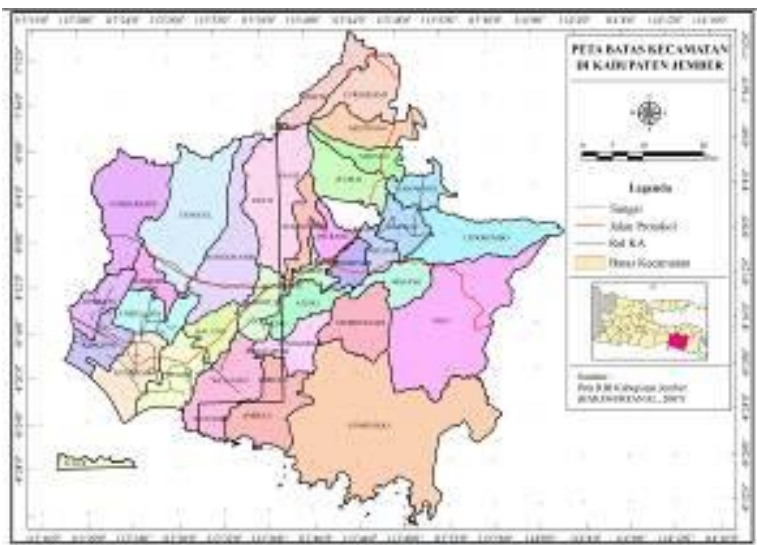

Gambar 1. Lokasi Penelitian, Kecamatan Kaliwates, Kabupaten Jember (Sumber: BAPPEDA Kab Jember, 2017)

Metodologi Penelitian

a. Deliniasi Zona

Pada kegiatan ini dilakukan pembuatan batas imajiner zona baru yang berisikan data nilai tanah. Hal-hal yang dipertimbangkan dalam pembuatan zona sebagai berikut :

a. Indikasi nilai tanah yang mirip

b. Memiliki karakteritik yang mirip

i. Aksesibilitas

ii. Peruntukan tanah (zoning)

iii. Identifikasi Penentu Nilai Tanah

b. Informasi Harga Tanah

Dalam perhitungan nilai tanah ini digunakan metode Perbandingan

Pendekatan Data Pasar (Market Data Approach).

c. Perhitungan Nilai Tanah

Dalam perhitungan nilai tanah ini digunakan metode Perbandingan
Pendekatan Data Pasar (Market Data Approach). Nilai tanah ini didapatkan dari data Informasi Harga Tanah yang di analisis, informasi harga tanah tidak dapat dipakai secara langsung, akan tetapi harus melalui penyesuaian-penyesuaian sehingga nilainya bisa didapatkan dengan cukup akurat.

d. Perhitungan NIR

Penentuan Nilai Indikasi Rata-rata (NIR) dilakukan dengan cara menjumlahkan minimal 3 data nilai tanah tersebut dan di ambil rata-rata sehingga mendapatkan NIR pada masing-masing zona. Zona yang tidak memiliki data harga jual, maka untuk ZNT tersebut, penentuan NIR dilakukan dengan cara memakai data pembanding dari zona yang ada, data yang pakai sebagai pembanding minimal 3 zona (ZNT). Dan setelah itu dilakukan analisis antara NIR di zona yang satu dengan yang lainnya.

e. Regresi Linier Berganda

Regresi linier berganda dilakukan untuk mengetahui besarnya pengaruh variabelvariabel yang telah ditentukan terhadap variabel nilai tanah di daerah penelitian. Dari hasil regresi linier berganda ini dapat diketahui apakah dari variabel penentu tersebut mempunyai pengaruh yang bersifat menambah harga tanah atau sebaliknya, mengurangi harga tanah di daerah penelitian.

f. Uji F

Uji $\mathrm{F}$ digunakan untuk mengetahui apakah variabel-variabel penentu nilai tanah secara bersama-sama/serentak berpengaruh signifikan terhadap harga tanah. Derajat signifikansi yang digunakan adalah 0.05 atau $5 \%$.

g. Uji T

Uji T digunakan untuk mengetahui apakah variabel-variabel penentu nilai tanah secara parsial berpengaruh nyata atau tidak terhadap harga tanah. Derajat signifikansi yang digunakan adalah 0.05 atau $5 \%$.

h. R-square $\left(R^{2}\right)$

Koefisien determinasi digunakan untuk menunjukkan berapa besar sumbangan model tersebut dapat mewakili harga tanah terhadap variabel penentu nilai tanah. 
i. Klasifikasi NIR Model

Variabel dari NIR diolah kembali menggunakan model untuk menghasilkan NIR baru yang kemudian diklasifikasikan menjadi NJOP.

j. Peta ZNT berdasarkan model

Pada peta ZNT ini diperlukan batas administrasi dan hasil deliniasi zona baru yang merupakan batas-batas zona nilai tanahnya. NIR ZNT dituangkan dalam sebuah tabel yang berisi kode ZNT beserta NIR. NIR yang digunakan adalah NIR hasil perhitungan model yang telah diklasifikasikan menjadi NJOP.

\section{k. Hasil Akhir}

Hasil akhir dari penelitian ini, yaitu model nilai tanah Kecamatan Kaliwates tahun 2018, peta ZNT Kecamatan Kaliwates tahun 2018 berdasarkan model, dan besar perubahan atau selisih NIR NJOP dengan NIR ZNT Kecamatan Kaliwates berdasarkan model.

\section{HASIL DAN PEMBAHASAN}

1. Hasil Deliniasi Zona

Pembuatan zona Kecamatan Kaliwates dibuat sejauh radius 3 kilometer dari pusat lokasi CBD (Lippo Plaza). Deliniasi zona ini dibuat berdasarkan Kep.Men.Keu. No.533 Tahun 2000 dimana zona nilai tanah dibatasi oleh batas penguasaan/pemilikan objek pajak atau batas alam (bersifat Imajiner). Dari hasil deliniasi zona, diperoleh 76 zona yang tersebar seperti padaGambar 2.

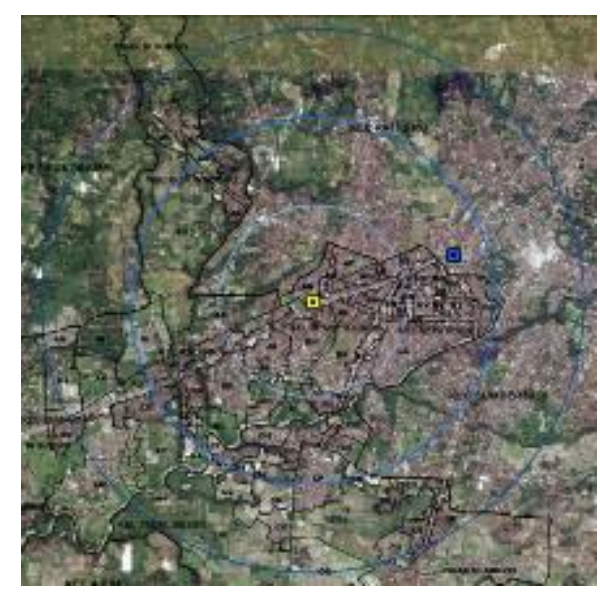

Gambar 2. Hasil deliniasi zona
Dalam pengambilan data sampel diambil sebanyak minimal 3 data informasi harga tanah pada setiap zona. Persebaran titik sampel yang telah di diperoleh dapat dilihat pada Gambar 3.

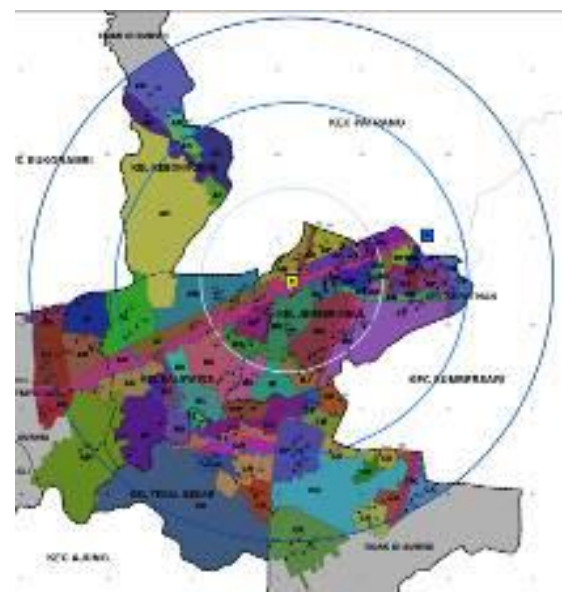

Gambar 3. Persebaran titik sampel yang diperoleh

\section{Perhitungan Nilai Tanah}

a. Indikasi Nilai Bumi

Data informasi harga tanah yang diperoleh berupa informasi harga tanah dan harga bangunan. Pada penelitian ini yang dibutuhkan adalah informasi harga tanah saja. Untuk data informasi harga bangunan harus diolah untuk mengetahui harga tanahnya atau Indikasi Nilai Bumi.

Indikasi Nilai Bumi tertinggi dengan nilai Rp 20.921.143/m2 berada di Jalan Gajah Mada. Hal tersebut dikarenakan sampel berupa ruko di pinggir jalan dan berada di radius $1 \mathrm{~km}$ dari Lippo Plaza. Untuk Indikasi Nilai Bumi terendah dengan nilai Rp $149.091 / \mathrm{m} 2$ berada di Perumahan Kebonagung. Hal tersebut dikarenakan sampel berupa rumah tinggal yang berada di radius $3 \mathrm{~km}$ Lippo Plaza.

b. Penyesuaian Data

Data informasi harga pasar tanah diolah menggunakan penyesuaian jenis data, sumber data, jenis penggunaan, luas tanah, kedudukan tanah, dan hak tanah. Penyesuaian tersebut akan dijelaskan masing-masing, sebagai berikut :

- Penyesuaian Jenis Data

Jenis data informasi harga tanah meliputi jenis data penawaran dan transaksi harga jual beli. Dimana data ini akan diberi persentase penambahan 
atau pengurangan. Pada penelitian ini, untuk data informasi transaksi harga jual beli diberikan persentase $0 \%$ karena merupakan harga yang digunakan pada saat transaksi. Untuk informasi harga penawaran diberikan persentase $-10 \%$ karena untuk harga penawaran masih bisa terjadi pengurangan harga sesuai kesepakatan. Hasil perhitungan persentase penyesuaian jenis data dapat di lihat pada dapat di lihat pada Tabel 1.

Tabel 1. Hasil Perhitungan persentase jenis data

\begin{tabular}{|c|c|c|c|}
\hline \multirow{2}{*}{ ZONA } & Jenis Data & \multirow{2}{*}{$\begin{array}{c}\text { Nilai } \\
\text { Penwaran/ } \\
\text { Transaksi }\end{array}$} & $\begin{array}{c}\text { Penyesuaian } \\
\text { Data }(\%)\end{array}$ \\
\hline & $\begin{array}{c}\text { Penawaran/ } \\
\text { Transaksi }\end{array}$ & & $\begin{array}{c}\text { Jenis Data } \\
(\%)\end{array}$ \\
\hline \multirow{3}{*}{ CI } & Penawaran & $\begin{array}{l}\mathrm{Rp} \\
120.000,000\end{array}$ & $-10 \%$ \\
\hline & Transaksi & $\begin{array}{l}\mathrm{Rp} \\
104,500,000\end{array}$ & $0 \%$ \\
\hline & Penawaran & $\begin{array}{l}\text { Rp } \\
225,000,000\end{array}$ & $-10 \%$ \\
\hline
\end{tabular}

Tabel 1. merupakan perhitungan persentase zona $\mathrm{Cl}$ yang memiliki jenis data penawaran dan transaksi, maka untuk jenis data penawaran diberikan persentase $-10 \%$, untuk jenis data transaksi diberikan persentase $0 \%$.

\section{- Penyesuaian Sumber Data}

Sumber data terdiri dari pemilik dan makelar. Untuk informasi yang didapatkan dari pemilik diberikan persentase $0 \%$, untuk makelar diberikan persentase hingga 5\% karena marketing akan menambahkan tidak lebih dari 5\% dari harga pemilik. Hasil perhitungan persentase penyesuaian sumber data dapat di lihat pada Tabel 2.

Tabel 2. Hasil Perhitungan persentase sumber data

\begin{tabular}{cccc}
\hline \multirow{2}{*}{ ZONA } & $\begin{array}{c}\text { Sumber } \\
\text { Data }\end{array}$ & $\begin{array}{c}\text { Nilai Penwaran/ } \\
\text { Transaksi }\end{array}$ & $\begin{array}{c}\text { Penyesuaian } \\
\text { Data (\%) }\end{array}$ \\
\cline { 3 - 4 } AN & Makelar & Rp 500,000,000 & $\begin{array}{c}\text { Sumber Data } \\
(\%)\end{array}$ \\
\cline { 2 - 4 } & Pemilik & $\operatorname{Rp~300,000,000~}$ & $-5 \%$ \\
\cline { 2 - 4 } & Pemilik & $\operatorname{Rp} 720,000,000$ & $0 \%$ \\
\hline
\end{tabular}

Tabel 2. merupakan perhitungan persentase zona AN yang memiliki sumber data makelar dan pemilik, maka pada sumber data makelar diberikan persentase $-5 \%$. Dan untuk smber data pemilik diberikan persentase $0 \%$.

- Penyesuaian Jenis Penggunaan

Jenis penggunaan tanah dibagi menjadi jenis penggunaan sawah, tanah kosong, rumah tinggal, dan ruko. Penyesuaian jenis penggunaan dilakukan dengan menambah atau mengurangi persentase harga tanah dari data pembanding berdasarkan data acuan. Data acuan dipilih berdasarkan jenis penggunaan yang dominan dari zona tersebut. Jenis penggunaan tanah untuk sawah diberikan persentase $0 \%$, tanah kosong hingga bangunan yang memiliki nilai komersial seperti koskosan, ruko, dan lain-lain akan diberikan persentase hingga $50 \%$ karena semakin tanah tersebut memperoleh manfaat/keuntungan maka harga tanah tersebut semakin tinggi nilainya. Hasil perhitungan persentase penyesuaian jenis penggunaan dapat di lihat pada Tabel 3.

Tabel 3. Hasil Perhitungan persentase jenis penggunaan

\begin{tabular}{|c|c|c|c|}
\hline \multirow{2}{*}{ ZONA } & $\begin{array}{c}\text { Keterangan } \\
\text { Aset }\end{array}$ & \multirow{2}{*}{$\begin{array}{c}\text { Nilai } \\
\text { Penwaran } \\
\text { /Transaksi }\end{array}$} & $\begin{array}{c}\text { Penyesuaian } \\
\text { Data }(\%) \\
\end{array}$ \\
\hline & $\begin{array}{c}\text { Jenis } \\
\text { Penggunaan }\end{array}$ & & $\begin{array}{c}\text { Jenis } \\
\text { Penggunaan }(\%)\end{array}$ \\
\hline \multirow{3}{*}{ AN } & $\begin{array}{l}\text { Rumah } \\
\text { Tinggal }\end{array}$ & Rp 500,000,000 & $0 \%$ \\
\hline & Tanah Kosong & Rp 300,000,000 & $20 \%$ \\
\hline & $\begin{array}{l}\text { Rumah } \\
\text { Tinggal }\end{array}$ & $\operatorname{Rp} 720,000,000$ & $0 \%$ \\
\hline
\end{tabular}

Tabel 3. merupakan perhitungan persentase zona AN yang memiliki jenis penggunaan rumah tinggal dan tanah kosong. Pada zona AN data acuannya adalah rumah tinggal dan data pembandingnya adalah tanah kosong. Maka pada jenis penggunaan rumah tinggal diberikan persentase $0 \%$. Dan untuk jenis penggunaan tanah kosong diberikan persentase $+20 \%$.

- Penyesuaian Luas Tanah 
Setiap harga tanah biasanya akan berbeda dari segi luasnya, jika suatu tanah ditawarkan tentunya tanah yang lebih besar luasnya akan lebih murah dibanding dengan lahan yang luasnya lebih kecil karena itu keluasan lahan menjadi faktor penyesuaian dengan menambah atau mengurangi persentase antara data acuan dan data pembanding. Untuk lahan yang luasnya lebih dari $500 \mathrm{~m} 2$ diberikan persentase sebesar 5\%. Hasil perhitungan persentase penyesuaian luas tanah dapat di lihat pada Tabel 4 .

Tabel 4. Hasil Perhitungan persentase luas tanah

\begin{tabular}{|c|c|c|c|}
\hline \multirow{2}{*}{ ZONA } & $\begin{array}{c}\text { Keterangan } \\
\text { Aset }\end{array}$ & \multirow{2}{*}{$\begin{array}{l}\text { Nilai Penwaran } \\
\text { /Transaksi }\end{array}$} & $\begin{array}{c}\text { Penyesuaian } \\
\text { Data }(\%)\end{array}$ \\
\hline & $\begin{array}{c}\text { Luas Tanah } \\
\left(\mathbf{m}^{2}\right)\end{array}$ & & $\begin{array}{c}\text { Luas Tanah } \\
\left(\mathbf{m}^{2}\right)\end{array}$ \\
\hline \multirow{3}{*}{$\mathrm{AM}$} & 995 & Rp 3.500.000.000 & $5 \%$ \\
\hline & 110 & $\mathrm{Rp} \quad 450.000 .000$ & $0 \%$ \\
\hline & 180 & $\begin{array}{ll}\mathrm{Rp} & 700.000 .000\end{array}$ & $0 \%$ \\
\hline
\end{tabular}

Tabel 4. merupakan perhitungan persentase zona $\mathrm{AM}$ yang memiliki luas lebih dari $500 \mathrm{~m} 2$. Pada zona AM data acuannya adalah luas tanah kurang dari $500 \mathrm{~m} 2$. Maka luas yang di atas $500 \mathrm{~m} 2$ diberikan persentase $+5 \%$.

- Penyesuaian Kedudukan Tanah

Kedudukan tanah ada dua yaitu pinggir jalan utama dan daerah perumahan, permukiman, lahan pertanian. Khusus untuk perumahan, permukiman, lahan pertanian, dibagi menjadi dalam, tengah, dan depan. Penyesuaiannya dilakukan dengan menambah atau mengurangi persentase antara data acuan dan data pembanding. Untuk tanah yang terletak di pinggir jalan akan diberikan persentase hingga 50\% karena nilai dari tanah tersebut akan bertambah dan bisa menghasilkan keuntungan yang lebih besar. Dan untuk dalam, tengah, dan depan diberikan penambahan persentase hingga $30 \%$. Hasil perhitungan persentase penyesuaian kedudukan tanah dapat di lihat pada Tabel 5.
Tabel 5. Hasil Perhitungan persentase kedudukan tanah

\begin{tabular}{|c|c|c|c|}
\hline \multirow{2}{*}{ ZONA } & \multirow{2}{*}{$\begin{array}{c}\text { Kedudukan } \\
\text { Tanah }\end{array}$} & \multirow{2}{*}{$\begin{array}{l}\text { Nilai Penwaran } \\
\text { /Transaksi }\end{array}$} & $\begin{array}{c}\text { Penyesuaian } \\
\text { Data }(\%)\end{array}$ \\
\hline & & & $\begin{array}{c}\text { Kedudukan } \\
\text { Tanah }(\%)\end{array}$ \\
\hline \multirow{3}{*}{$\mathrm{AP}$} & Dalam & $\begin{array}{ll}\mathrm{Rp} & 170.000 .000\end{array}$ & $0 \%$ \\
\hline & Dalam & $\mathrm{Rp} \quad 300.000 .000$ & $0 \%$ \\
\hline & Pinggir Jalan & Rp 2.800.000.000 & $-50 \%$ \\
\hline
\end{tabular}

Tabel 5. merupakan perhitungan persentase zona AP yang memiliki kedudukan tanah dalam dan pinggir jalan. Pada zona AP data acuannya adalah kedudukan tanah dalam. Maka kedudukan tanah pinggir jalan diberikan persentase $-50 \%$.

Penyesuaian Jenis Hak Tanah

Jenis hak tanah sangat berpengaruh terhadap nilai tanah, tanah yang mempunyai sertifikat tentunya akan mempunyai nilai lebih tinggi dibandingkan dengan tanah yang tidak bersertifikat, karena kekuatan kepemilikan tanah yang bersertifikat tentunya lebih kuat secara hukum. Untuk lahan yang mempunyai status tanah selain Sertifikat Hak Milik (SHM) diberikan penambahan persentase hingga $10 \%$. Hasil perhitungan persentase status hak tanah dapat di lihat pada Tabel 6 .

Tabel 6. Hasil Perhitungan persentase status hak tanah

\begin{tabular}{|c|c|c|c|}
\hline \multirow{2}{*}{ ZONA } & \multirow{2}{*}{$\begin{array}{c}\text { Status } \\
\text { Hak } \\
\text { Tanah }\end{array}$} & \multirow{2}{*}{$\begin{array}{l}\text { Nilai Penwaran } \\
\text { /Transaksi }\end{array}$} & $\begin{array}{c}\text { Penyesuaian } \\
\text { Data }(\%)\end{array}$ \\
\hline & & & $\begin{array}{l}\text { Status Hak } \\
\text { Tanah }(\%)\end{array}$ \\
\hline \multirow{3}{*}{$\mathrm{BP}$} & Lain-lain & $\begin{array}{ll}\mathrm{Rp} & 150.000 .000\end{array}$ & $5 \%$ \\
\hline & SHM & Rp 3.000.000.000 & $0 \%$ \\
\hline & SHM & Rp 2.300.000.000 & $0 \%$ \\
\hline
\end{tabular}

Tabel 6. merupakan perhitungan persentase zona BP yang memiliki status hak tanah SHM dan selain SHM (Lain-lain). Maka status hak tanah selain SHM diberikan persentase $+5 \%$.

\section{Perhitungan Nilai Indikasi Rata-Rata (NIR)}

a. NIR Setiap Zona

Nilai Indikasi Rata-Rata (NIR) diperoleh dari rata-rata Indikasi Nilai Pasar Tanah. NIR 
setiap zona memiliki 3 Indikasi Nilai Tanah/m2. Sehingga penentuan NIR dilakukan dengan cara menjumlahkan 3 data Indikasi Nilai Tanah/m2 tersebut pada setiap zona dan diambil rata-rata sehingga mendapatkan Nilai Indikasi Rata-Rata (NIR). NIR yang diperoleh memiliki bermacam-macam harga. Hasil Perhitungan NIR Setiap Zona dapat dilihat pada Tabel 7.

Tabel 7. Hasil Perhitungan NIR Setiap Zona

\begin{tabular}{|c|c|c|c|}
\hline ZONA & $\begin{array}{c}\text { No. } \\
\text { Sampel }\end{array}$ & $\begin{array}{c}\text { Indikasi Nilai } \\
\text { Pasar Tanah / } \\
\mathbf{m}^{2}\end{array}$ & $\begin{array}{l}\text { Nilai Indikasi } \\
\text { Rata-Rata } \\
\text { (NIR) }\end{array}$ \\
\hline \multirow{3}{*}{$\mathbf{A U}$} & 16 & Rp 18.200.000 & \multirow{3}{*}{ Rp 18.080.190 } \\
\hline & 83 & $\operatorname{Rp} 18.257 .600$ & \\
\hline & 99 & $\operatorname{Rp} 17.782 .971$ & \\
\hline \multirow{3}{*}{ AG } & 26 & 249.669 & \multirow{3}{*}{$\mathrm{Rp}$} \\
\hline & 124 & 245.455 & \\
\hline & 125 & 262.500 & \\
\hline
\end{tabular}

NIR tertinggi berada di zona AU dengan Rp18,080,190/m2. Hal tersebut dikarenakan lokasinya yang berada di radius $1 \mathrm{~km}$ dari Lippo Plaza dan merupakan daerah komersil dengan bangunan rata-rata adalah ruko sehingga apabila memiliki tanah di zona AU maka akan memperoleh lebih banyak keuntungan. Untuk NIR terendah berada di zona AG dengan $252,541 / \mathrm{m} 2$. Hal tersebut dikarenakan lokasinya berada di radius 3 km dari Lippo Plaza dan merupakan daerah lahan pertanian.

b. Perhitungan NIR dari NIR Zona Lain

Penentuan Nilai Indikasi Rata-Rata (NIR) dari zona lain dilakukan dengan memakai data pembanding dari zona yang telah memiliki NIR. Zona pembanding yang digunakan adalah 3 zona yang memiliki karakteristik yang sama atau yang berdekatan, hal ini dimaksudkan agar tingkat penyesuaian tidak terlalu berbeda. Dari 3 zona tersebut disesuaikan datanya sehingga memperoleh Nilai Tanah Setelah Penyesuaian/m2 yang kemudian diambil nilai rata-rata sehingga didapatkan Nilai Indikasi Rata-Rata (NIR) pada zona tersebut. Adapun Penyesuaian dalam Analisis Penentuan Nilai Indikasi Rata-Rata (NIR) dengan Zona Lain adalah:

- Penyesuaian Lokasi
Pengaruh lokasi pada penelitian ini dipengaruhi oleh kedudukan zona terhadap aksesbilitas ke zona tersebut melalui jenis jalan (arteri, kolektor, lokal, dan lingkungan). Penyesuaian lokasi dilakukan dengan memberikan nilai persentasi hingga $50 \%$ sesuai dengan kondisi dilapangan.

- Penyesuaian Jenis Penggunaan

Dalam penelitian ini, jenis penggunaannya berupa lahan pertanian, permukiman, perumahan, dan komersil. Penyesuaian jenis penggunaan dilakukan dengan memberikan nilai persentasi hingga $50 \%$ sesuai dengan kondisi dilapangan.

\section{Regresi Linier Berganda}

Penelitian ini menggunakan model regresi linier berganda untuk menganalisis pengaruh Jarak ke Lippo (X1), Jarak ke Pusat Kota (X2), Lebar Jalan (X3), dan Kondisi Lingkungan (X4) terhadap Nilai Tanah (Y). Hasil analisis diperoleh berbagai model berikut :

$$
\begin{gathered}
\mathrm{Y}=26,187+38,921 \text { Komersil }+ \text { 0,049 X2 - } \\
7,002 \times 1
\end{gathered}
$$

Untuk kondisi lingkungan komersil akan menambah nilai $Y$ sebesar Rp 38,921. Dan untuk setiap kenaikan $\mathrm{X} 2$ sebesar 1 satuan, maka nilai $\mathrm{Y}$ akan bertambah sebesar $\mathrm{Rp}$ 0,049 karena Keduanya merupakan hubungan searah. Dan untuk setiap kenaikan $X 1$ sebesar 1 satuan, maka nilai $Y$ akan berkurang sebesar $R p$ 7,002 karena Keduanya merupakan hubungan tidak searah.

a. Pengujian Serentak (Uji F)

Pengujian serentak (uji F) untuk mengetahui apakah semua variabel yang dimasukkan dalam model mempunyai pengaruh secera serentak terhadap variabel dependan Harga Tanah (Y). Adapun hasil pengujian serentak adalah sebagai berikut.

Tabel 8. Pengujian Serentak

\begin{tabular}{lll}
\hline F-hitung & F-tabel & P-value \\
\hline 51,702 & 2,662 & 0,000 \\
\hline
\end{tabular}

Tabel 8. menunjukan bahwa Hasil analisis pengujian serentak dengan nilai $\mathrm{F}$ hitung pada model lebih besar dari nilai F- 
tabel 2,662 yaitu 51,702 dan nilai $p$-value adalah 0,000 yang lebih kecil dari $\alpha$ yaitu 0,05 , sehingga terdapat pengaruh signifikan antara variabel Komersil, Jarak ke Pusat Kota (X2), dan Jarak ke Lippo Plaza (X1) terhadap variabel $Y$ yaitu harga tanah.

b. Pengujian Parsial (Uji t)

Pengujian dilanjutkan pada pengujian parsial guna mengetahui koefisien atau masing-masing variabel yang berpangaruh pada pemodelan regresi.

Tabel 9. Pengujian Parsial

\begin{tabular}{lccc}
\hline Variabel & $\mathbf{t}_{\text {hitung }}$ & $\mathbf{t}_{\text {tabel }}$ & $\mathbf{P}_{\text {-value }}$ \\
\hline Komersil & 9,075 & 1,975 & 0,000 \\
\hline Jarak ke Pusat Kota & 4,814 & 1,975 & 0,000 \\
\hline Jarak ke Lippo Plaza & $-3,288$ & 1,975 & 0,001 \\
\hline
\end{tabular}

*Nilai tabel mutlak

Tabel 9. menunjukkan bahwa hasil analisis pengujian serentak dengan Nilai $p$ value lebih kecil dari nilai $\alpha$ yaitu 0.05 , dan nilai thitung Komersil 9,075, Jarak ke Pusat Kota 4,814, Jarak ke Lippo Plaza -3,288 lebih besar dari nilai ttabel 1,975. Dari hasil perhitungan Uji Parsial terdapat pengaruh yang signifikan antara Komersil, Jarak ke Pusat Kota, Jarak ke Lippo Plaza Komersil terhadap Harga Tanah.

\section{c. R-Square}

Berikut adalah hasil pengujian RSquare:

Tabel 10. Pengujian R-Square

\begin{tabular}{ll}
\hline Variabel & R-Square \\
\hline Koefisien & $49,7 \%$ \\
\hline
\end{tabular}

Tabel 10. menunjukkan hasil analisis pengujian R-Square bahwa faktor-faktor yang mempengaruhi Harga Tanah dapat dijelaskan oleh variabel predikator dengan persentase $49,7 \%$, sementara sisanya dijelaskan oleh faktor lain yang tidak masuk dalam model. Melihat persentase yang hanya sebesar $49,7 \%$ dapat diambil analisa bahwa model yang digunakan pada penelitian kali ini cukup baik sehingga model yang dihasilkan dapat diterapkan.

\section{Klasifikasi NIR}

a. Klasifikasi NIR Model

Hasil klasifikasi NIR terendah pada kelas 72 yang terdapat pada zona AV dan zona CR dengan NJOP sebesar Rp $394.000 / \mathrm{m} 2$. Hal tersebut disebabkan karena lokasinya yang merupakan permukiman dan perumahan yang berada di radius $3 \mathrm{~km}$ dari Lippo Plaza. Untuk klasifikasi NIR tertinggi pada kelas 58 yang terdapat pada zona $\mathrm{AU}$ dengan NJOP sebesar Rp $2.013 .000 / \mathrm{m} 2$. Hal tersebut disebabkan karena lokasinya yang merupakan lahan komersil dan berada di radius $1 \mathrm{~km}$ dari Lippo Plaza. Untuk klasifikasi NIR terendah dapat dilihat pada Tabel 11. Untuk klasifikasi NIR tertinggi dapat dilihat pada tabel 12.

Tabel 11. Klasifikasi NIR terendah berdasarkan model

\begin{tabular}{|c|c|c|c|c|c|c|c|c|c|c|c|c|}
\hline \multirow{2}{*}{$\begin{array}{l}\text { KODE } \\
\text { ZONA }\end{array}$} & \multirow{2}{*}{\multicolumn{2}{|c|}{ MODEL / m2 }} & \multirow{2}{*}{\multicolumn{2}{|c|}{$\begin{array}{c}\text { NIR } \\
\text { MODEL/ } \\
\mathbf{m} 2\end{array}$}} & \multicolumn{8}{|c|}{$\begin{array}{l}\text { PERATURAN BUPATI TENTANG KLASIFIKASI DAN } \\
\text { PENETAPAN NILAI JUAL OBJEK PAJAK SEBAGAI DASAR } \\
\text { PENGENAAN PAJAK BUMI DAN BANGUNAN }\end{array}$} \\
\hline & & & & & $\begin{array}{l}\text { Kelas } \\
\text { Tanah }\end{array}$ & & engelomp & $\begin{array}{l}\text { in Nil } \\
\text { Rp/m }\end{array}$ & Iual $\mathrm{H}$ & & Nila & $\begin{array}{l}\text { al Objek } \\
\text { jak } \\
\text { P)/m2 }\end{array}$ \\
\hline \multirow{3}{*}{$\mathrm{AV}$} & $\mathrm{Rp}$ & 541.234 & \multirow{3}{*}{$\mathrm{Rp}$} & \multirow{3}{*}{389.442} & \multirow{3}{*}{072} & \multirow{3}{*}{$\mathrm{Rp}$} & \multirow{3}{*}{362.000} & \multirow{3}{*}{$\mathrm{s} / \mathrm{d}$} & \multirow{3}{*}{$\mathrm{Rp}$} & \multirow{3}{*}{426.000} & \multirow{3}{*}{$\mathrm{Rp}$} & \multirow{3}{*}{394.000} \\
\hline & $\mathrm{Rp}$ & 306.234 & & & & & & & & & & \\
\hline & $\mathrm{Rp}$ & 320.858 & & & & & & & & & & \\
\hline \multirow{3}{*}{ CR } & $\mathrm{Rp}$ & 384.984 & \multirow{3}{*}{$\mathrm{Rp}$} & \multirow{3}{*}{395.211} & \multirow{3}{*}{072} & \multirow{3}{*}{$\mathrm{Rp}$} & \multirow{3}{*}{362.000} & \multirow{3}{*}{ s/d } & \multirow{3}{*}{$\mathrm{Rp}$} & \multirow{3}{*}{426.000} & \multirow{3}{*}{$\mathrm{Rp}$} & \multirow{3}{*}{394.000} \\
\hline & $\mathrm{Rp}$ & 459.226 & & & & & & & & & & \\
\hline & $\mathrm{Rp}$ & 341.422 & & & & & & & & & & \\
\hline
\end{tabular}

Tabel 12. Klasifikasi NIR tertinggi berdasarkan model

\begin{tabular}{|c|c|c|c|c|c|c|c|c|}
\hline \multirow{2}{*}{$\begin{array}{l}\text { KODE } \\
\text { ZONA }\end{array}$} & \multirow{2}{*}{ MODEL / m2 } & \multirow{2}{*}{$\begin{array}{l}\text { NIR } \\
\text { MODEL } / \\
\text { m2 }\end{array}$} & \multicolumn{6}{|c|}{$\begin{array}{l}\text { PERATURAN BUPATI TENTANG KLASIFIKASI DAN } \\
\text { PENETAPAN NILAI JUAL OBJEK PAJAK SEBAGAI DASAR } \\
\text { PENGENAAN PAJAK BUMI DAN BANGUNAN }\end{array}$} \\
\hline & & & $\begin{array}{l}\text { Kelas } \\
\text { Tanah }\end{array}$ & Pengelompo & $\begin{array}{l}\text { an Ni } \\
\mathrm{Rp} / \mathrm{m}\end{array}$ & ual Bumi & & $\begin{array}{l}\text { ual Objek } \\
\text { Pajak } \\
\text { OP//m2 }\end{array}$ \\
\hline \multirow{3}{*}{ AT } & Rp $\quad 2.087 .192$ & \multirow{3}{*}{ Rp 1.972 .601} & \multirow{3}{*}{058} & \multirow{3}{*}{$\operatorname{Rp} 1.934 .000$} & \multirow{3}{*}{$\mathrm{s} / \mathrm{d}$} & \multirow{3}{*}{ Rp 2.091.000 } & \multirow{3}{*}{$\mathrm{Rp}$} & \multirow{3}{*}{ 2.013.000 } \\
\hline & Rp $\quad 2.111 .613$ & & & & & & & \\
\hline & $\begin{array}{ll}\mathrm{Rp} & 1.718 .998 \\
\end{array}$ & & & & & & & \\
\hline
\end{tabular}

\section{Peta Zona Nilai Tanah}

Peta ZNT Kecamatan Kaliwates Kabupaten Jember berdasarkan model dapat dilihat di Gambar 5.

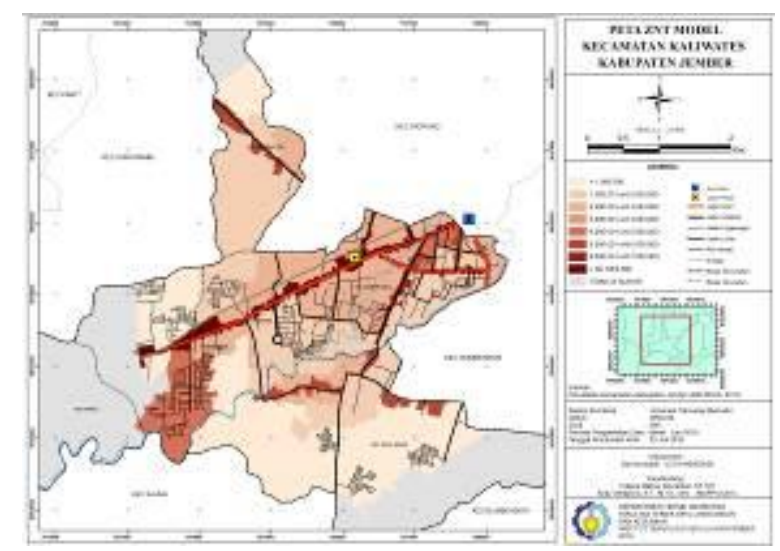

Gambar 5. Peta Zona Nilai Tanah Berdasarkan Model 
Warna pada peta mendefinisikan tinggi rendahnya harga tanah di wilayah tersebut, semakin warna merah pada peta semakin tua/pekat, maka harga tanah pada wilayah tersebut tersebut semakin tinggi. Berdasarkan Gambar 5. yang memiliki nilai paling tinggi dengan rentang harga > Rp 7.000.000 adalah di wilayah sepanjang Jalan Gajah Mada dan Jalan Kenanga. Wilayah tersebut berada di wilayah komersil dan berada di radius $1 \mathrm{~km}$ dari Lippo Plaza. Untuk wilayah yang memiliki nilai paling rendah dengan rentang harga $<\mathrm{Rp}$ 1.000.000 adalah di wilayah Jalan Ikan Kakap, Jalan Cadika, Jalan Ikan Paus, Perumahan Darma Alam, Perumahan Mandiri Land, Jalan Hayam Wuruk XIII, Jalan Gajah Mada XXXI, Jalan Moh Yamin, Perumahan Royal City, Perumahan Tegal Besar Permai II, Jalan Teuku Umar gg VIII, Perumahan Bumi Tegal Besar, Jalan Teuku Umar gang pasir emas, Perumahan Pondok Gede Permai, Jalan Basuki Rahmat VII, Jalan Basuki Rahmat, dan Jalan Basuki Rahmat V. Wilayah tersebut merupakan lahan pertanian, perumahan, dan permukiman serta berada di radius $3 \mathrm{~km}$ dari Lippo Plaza.

\section{KESIMPULAN}

Kesimpulan yang diperoleh dari penelitian adalah sebagai berikut :

1. Berdasarkan hasil pemodelan menggunakan regresi linier berganda variabel Komersil, Jarak ke Pusat Kota (X2) dan Jarak ke Lippo Plaza (X1) mempengaruhi nilai tanah secara signifikan. Model yang diperoleh yakni $Y=$ $26,187+38,921$ Komersil + 0,049 X2 - 7,002 $\mathrm{X} 1$.

2. Zona atau daerah yang memiliki nilai tanah paling tinggi merupakan lahan komersil yang berada di radius $1 \mathrm{~km}$ dari Lippo Plaza. Untuk nilai tanah paling rendah merupakan lahan pertanian, permukiman, dan perumahan yang berada di radius $3 \mathrm{~km}$ dari Lippo Plaza.

\section{UCAPAN TERIMA KASIH}

Penulis mengucapkan terima kasih kepada BAPPEDA Kabupaten Jember dan BAPENDA Kabupaten Jember yang telah menyediakan data. Serta, pembimbing dan teman-teman yang menjadi tempat diskusi dalam pengerjaan penelitian ini.

\section{DAFTAR PUSTAKA}

Kurniati, N. (2017). Analisis Pengaruh Daerah Rawan Banjir Terhadap Nilai Tanah Disekitarnya (Studi kasus: Kecamatan Sukolilo Kota Surabaya).

Prawitaningrum, R. (2017). Resmikan Mal Pertama di Jember, Lippo Gelontarkan Rp 1,2 Triliun. detikFinance

Purwaningsih, I. (2016). Statistik Daerah Kecamatan Kaliwates 2016. Jember: BPS Kabupaten Jember.

Safitri, H. Y. (2016). Analisis Pengaruh Lokasi Central Business District Terhadap Nilai Tanah Di Daerah Sekitarnya. Jurnal Teknik POMITS, 2(1), 1-5.

Setia, D. A. (2017,). Kecamatan Kaliwates, Pusat Perekonomian Kota Jember. Rabu, 7 Februari 2018. Retrieved from www.jawapos.com

.Yullyan, S. E. (2016). Pemodelan Nilai Tanah Dengan Menggunakan Metode Regresi Linier Sepanjang Ruas Jalan Ir Soekarno Pada Jalur Middle East Ring Road (MERR) II-C Di Kecamatan Rungkut. Institut Teknologi Sepuluh Nopember (ITS). 